
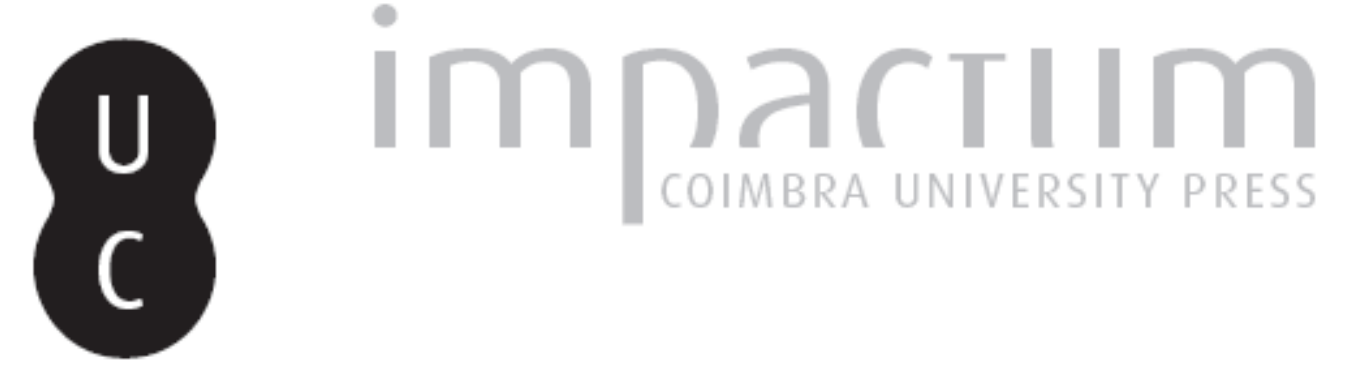

\title{
Environmental management of the buffer zones of conservation units in urban areas
}

\author{
Autor(es): $\quad$ Ribeiro, Marta Foeppel; Freitas, Marcos Aurélio Vasconcelos de; Costa, \\ Vivian Castilho da
}

Publicado por: Associação Portuguesa de Riscos, Prevenção e Segurança

URL

persistente:

URI:http://hdl.handle.net/10316.2/36059

DOI:

DOI:http://dx.doi.org/10.14195/1647-7723_18_16

Accessed : $\quad$ 26-Apr-2023 12:56:05

A navegação consulta e descarregamento dos títulos inseridos nas Bibliotecas Digitais UC Digitalis, UC Pombalina e UC Impactum, pressupõem a aceitação plena e sem reservas dos Termos e Condições de Uso destas Bibliotecas Digitais, disponíveis em https://digitalis.uc.pt/pt-pt/termos.

Conforme exposto nos referidos Termos e Condições de Uso, o descarregamento de títulos de acesso restrito requer uma licença válida de autorização devendo o utilizador aceder ao(s) documento(s) a partir de um endereço de IP da instituição detentora da supramencionada licença.

Ao utilizador é apenas permitido o descarregamento para uso pessoal, pelo que o emprego do(s) título(s) descarregado(s) para outro fim, designadamente comercial, carece de autorização do respetivo autor ou editor da obra.

Na medida em que todas as obras da UC Digitalis se encontram protegidas pelo Código do Direito de Autor e Direitos Conexos e demais legislação aplicável, toda a cópia, parcial ou total, deste documento, nos casos em que é legalmente admitida, deverá conter ou fazer-se acompanhar por este aviso.

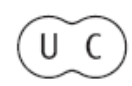




\section{territorium}

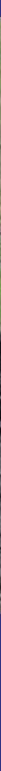

\section{Afirmar as Ciências Cindínicas}

Revista da Associação Portuguesa de Riscos, Prevenção e Segurança 
Marta Foeppel Ribeiro

nstitution: University of the State of Rio de Janeiro IVIG/COPPE/Federal University of Rio de Janeiro mfoeppel@gmail.com

Marcos Aurélio Vasconcelos de Freitas Institution: IVIG/COPPE/ Federal University of Rio de Janeiro mfreitas@ivig.coppe.ufrj.br

Vivian Castilho da Costa Institution: University of the State of Rio de Janeiro vivianuerj@gmail.com

\begin{abstract}
RESUMO
Gestão ambiental de zonas de amortecimento de unidades de conservação em áreas urbanas - Este artigo trata, sob o ponto de vista jurídico, da importância da definição, do diagnóstico, do estabelecimento de critérios de uso e ocupação e do monitoramento de zonas de amortecimento de unidades de conservação de proteção integral. A gestão de unidades de conservação deve considerar as áreas do seu entorno, buscando-se evitar os avanços de atividades antrópicas externas sobre os ecossistemas naturais dentro dos seus limites.

Palavras chave: Gestão ambiental, unidades de conservação, zonas de amortecimento, planos de manejo, legislação ambiental.
\end{abstract}

\title{
RESUMEN
}

Gestión ambiental de zonas de amortecimiento de unidades de conservación en áreas urbanas - Este artículo trata, desde el punto de vista jurídico, la importancia de la definición, el diagnóstico, el establecimiento de criterios de uso y ocupación y el monitoreo de zonas de amortecimiento de unidades de conservación de protección integral. La gestión de unidades de conservación debe considerar las áreas del entorno, buscando evitar el avance de actividades antrópicas externas sobre los ecosistemas naturales dentro de sus límites.

Palabras clave: Gestión ambiental, unidades de conservación, zonas de amortecimiento, planes de gestión, legislación medioambiental.

\section{RÉSUMÉ}

La gestion environnementale des zones tampons des unités de conservation dans les aires urbaines - Cet article traite, sous le point de vue juridique, de l'importance de la définition, du diagnostique, de l'établissement des critères d'utilisation et d'occupation et du monitorage des zones d'amortissement (zones tampons) des unités de conservation de la protection intégrale. La gestion des unités de conservation doit considérer les surfaces environnantes, en cherchant à éviter les avancements des activités anthropiques externes sur les écosystèmes naturels dans leurs limites. Mots-clé: Gestion environnementale, unités de conservation, zones tampons, plans de gestion, législation environnementale.

\section{ABSTRACT}

Environmental management of the buffer zones of conservation units in urban areas - This article examines, from a legal standpoint, the importance of the definition, diagnosis and establishment of criteria for the use, occupation and monitoring of buffer zones for conservation units of integral protection. The management of conservation units should take into account the areas surrounding the unit, so as to avoid the encroachment of external anthropic activities on to the natural ecosystems within the unit boundaries.

Key words: Environmental management, conservation units, buffer zones - management plans - environmental legislation.

\footnotetext{
* O texto deste artigo corresponde à comunicação apresentada ao II Congresso Internacional de Riscos e VI Encontro Nacional, tendo sido submetido para revisão em 01-06-2010, tendo sido aceite para publicação em 12-08-2010.

Este artigo é parte integrante da Revista Territorium, n. ${ }^{\circ} 18,2011$, ${ }^{\circledR}$ RIscos, ISBN: 0872- 8941.
} 


\section{Introduction}

The trend of intense urbanization which has been increasing in the world since the early years of the twentieth century has led to profound modification in the natural characteristics of geographical space, including the removal of original plant cover, the impermeabilization of extensive areas, channeling of rivers and modification of the hydrological cycle. These modifications have led to significant environmental consequences, alterations in climatic variables and in the pluvial and fluvial regimes, erosion in headwater streams and accelerated erosive processes, landslides and urban flooding.

Population shifts in the last one hundred years have resulted in three quarters of the world's population now living in cities. This in turn has increased pressures on the environment and its natural resources. These pressures include removal of plant cover, both in low lying areas and hillsides, to make room for new construction. The process of forestry fragmentation, principally on hillsides, has led to environmental imbalance such as microclimatic changes, reduction of inflow into fluvial headwaters from internal sources and also diminished protection of such waters against erosive agents, the removal of natural protection of the soil against pluvial erosion and the action of wind, the lowering of the water table and an increase in surface runoff.

The establishment of protected areas or conservation units is one of ways of mitigating the potential risks of human activities that threaten the conservation of biodiversity. The aim of such areas is to preserve representative parts of the ecosystem and their ecological processes and biodiversity (VITALLI, 2007). The National System of Conservation Units (Sistema Nacional de Unidades de Conservação) - SNUC (2000) defines a Conservation Unit as a "a territorially protected space including its jurisdictional waters, which has relevant (significant) natural characteristics and which was legally established by the Public Authority with the aim of conservation [within] defined limits, in accordance with a special administrative regime to which adequate guarantees of protection apply".

According to Milano (2001, p. 4), the evolution of environmental issues led to the creation of conservation units, the first of which was the Yellowstone National Park, in the United States, in 1872, the establishment of which is considered to be the "modern benchmark in the protection of natural resources against the destructive processes of human action".

In general terms, the first international conventions related to the environment were concerned with the protection of beautiful scenery, and within this framework a Convention on the Preservation of Fauna and Flora in its Natural State was signed in London in 1933.

The starting point for the development of environmental regulation in Brazil was the introduction of the Brazilian Forestry Code, by means of Federal Decree n० 23793 in 1934 and, shortly thereafter, to the establishment of the first Brazilian National Parks: Itatiaia (1937) and Serra dos Órgãos e Iguaçu (1939) (VITALLI, 2007).

Latin America, including Brazil, is rich in biodiversity, and is the focus of world attention in terms of nature conservation. Countries in the region use conservation units as protection mechanisms (MILANo, 2001).

In Brazil, the forms of environmental protection of the remaining native vegetation or secondary forest are gradually emerging in response to the provisions of the 1988 Federal Constitution which, in article 225, imposes on public authorities and society as a whole the duty to preserve an ecologically balanced environment for the present and future generations.

The legal protection of conservation units certainly advanced with the (New) Forestry Code (Law $\mathrm{N}^{\circ}$ 4771) which was introduced in 1965, prior to the 1988 Constitution, and set out legal rules for the creation of parks, biosphere reserves and forests, it was only in 2000 that Brazil established a National System of Conservation Units ("Sistema Nacional de Unidades de Conservação SNUC") through the Law $\mathrm{n}^{\circ}$ 9985, known as the "SNUC Law" (Costa et al, 2009).

The SNUC Law was the result of a lengthy legislative process. It seeks, in general terms, to establish limits on activities that might undermine the ecological function of the conservation unit or lead to the extinction of species or inhumane treatment of animals.

Increasing awareness both worldwide and in Brazil of the fact that activities undertaken in the areas surrounding conservation units were capable of endangering the ecosystems led to the need for additional mechanisms to ensure effective conservation. In fact, as early on as 1986 the International Union for the Conservation of Nature (IUCN) was already warning against the risks of treating conservation units as "islands" (Diegues, 2004 apud VitaLLI, 2007).

In response to these concerns, the provisions of the SNUC law not limited to the boundaries of the conservation units. The law also demands that an area surrounding the units be established as a buffer zone. Restrictions are placed on the use and occupation of the land within this zone as a means of minimizing damage form the increasing pressure on the protected spaces. The buffer zone acts as a filter, aimed at preventing external anthropic activities from prejudicing the natural ecosystems within the conservation unit. 
Therefore, diagnosing external risks, establishing criteria for use and occupation and the management of the buffer zones are as important as adequate management of the conservation units themselves in order to prevent harmful external factors from encroaching onto the protected areas.

\section{An overview of the National System of Conservation Units (SNUC) -SNUC Law - nº 9985/2000}

The SNUC Law seeks to "guarantee the preservation and restoration of essential ecological processes, the management of ecosystems, the monitoring of entities responsible for carrying out research in the protected areas, the definition of the protected territorial spaces, with the emphasis being on the component parts, in addition to the areas themselves." (VASQUES, 2008, p. 3).

The conservation units defined and regulated by the SNUC Law fall into two main groups: direct use units and indirect use units, as the integral protection units. The aim of the latter is to preserve the ecosystem by permitting only indirect use of the unit's natural resources (Costa et al., 2009). This is fundamental, particularly in parks located in urban areas and subject to increasing pressures due to the demand for areas of land to occupy. Urban parks frequently contain residual areas of forest, normally limited to high grounds or areas that are difficult to access (COSTA et al., op. cit.).

Art. $2^{\circ}$ of the SNUC Law (sub-paragraphs XVII, XVIII and $\mathrm{XIX)}$ defines other key features of the conservation units such as unit management plans, buffer zones and ecological corridors. The first two are of direct interest to this paper.

In accordance with Art. $2^{\circ}, \quad X V I I$ defines a Unit Management Plan as

"the technical document via which, based on the general objectives of a conservation unit, sets out the manner in which it is to be divided into zones and the norms that are to govern the use of the area and the management of its natural resources, including the provision of the physical structures necessary for the management of the unit."

Article 27, paragraph 1 of the same law states that the "Unit Management Plan is to apply to the conservation unit itself, its buffer zone and the ecological corridors, and include measures aimed at promoting integration of the unit with the economic and social life of the neighboring communities". In art. $2^{\circ}$, XVIII a buffer zone (or "protective belt") is defined as:

"[the area] surrounding a conservation unit, in which human activities are subject to specific norms and restrictions, aimed at minimizing negative impacts on the unit".
The management plan is preventative in nature and should contain all the norms governing the conservation unit and its surrounding areas, individually analyzing and taking into account all the particular characteristics of a given unit (VASQUES, 2008).

In practice, however, despite the fact that it is essential to have surveys identifying and diagnosing the needs of areas surrounding conservation units, few unit management plans in Brazil clearly define a buffer zone and take it into account in the planning and management of the natural resources of the unit (COSTA et al., 2009).

Public participation is only provided for in some management plans, such as those covering conservation units known as Extractive Reserves, Sustainable Development Reservations and Environmental Protection Areas. MACHADO (2001, p. 256) criticizes this omission, stating that "the correct drawing up of a management plan transcends the limits of the conservation unit. The participation of the public would enable permanent transparency in the management of the units.

The Unit Management Plan should, in principle, contain detailed information as to the physical, biological, landuse, social and cultural characteristics of the protected area and its surroundings (VASQUES, 2008). The protected are should then be analyzed in terms of its regional context. The principal objective of the conservation unit should be explicitly set out in the document, as should the details of any action or measures needed to attain the objectives.

The Unit Management Plan should be drawn up within five years of the date of establishment of the conservation unit. In practice, the high cost of drawing up such plans and lack of adequate financial resources are frequently cited by the responsible bodies as grounds for their failure to comply with this duty. (VASQUES, op. cit.).

According to MACHADO (2001), pending completion of the Unit Plan, an emergency plan should be drawn up governing unit-related activity on a provisional basis. The absence of any such plan constitutes grounds for the filing of a Public Civil Lawsuit seeking a court order requiring the responsible authorities to draw up and implement the necessary directives.

The evolution of legal regulation of the buffer zones of Conservation Units in Brazil

Although it was only in the year 2000, with the introduction of the SNUC Law (art. 25) that it was legally established that conservation units (with the exception of Private Nature Reserves and Areas of Environmental Protection) were to have a buffer zone, statutory provisions had been introduced as early as the 1960s to govern the use and occupation of the areas surrounding 'strategic' lands. 
In 1967, art. 10 of Law n 5197 established a zone of 5 km adjacent to certain official establishments and publicly owned reservoirs, prohibiting therein the destruction, exploitation or hunting of wildlife (Vı, 2001).

The term 'buffer zone' is not used in Decree 84017, of September 21, 1979, in relation to the Regulation of Brazilian National Parks. Reference is made instead to "special use zones" (art. 7, VII), with the stipulation that, whenever possible, "installations necessary for the administration, maintenance and services in the park be installed in on its edges, so as not to conflict with its natural character" (VIO, 2001, p. 351).

Decree $99.274 / 1990$ in effect made provision for buffer zones by its reference to the "surrounding areas" of conservation units, stipulating that any activity, within a range of 10 kilometers, that might affect the biota, was subject to regulations issued by the National Council for the Environment (Conselho Nacional de Meio Ambiente - CONAMA) (VIo, op. cit.; OliveIra e Santos, 2004). CONAMA is the federal consultative and deliberative body which has powers to monitor the implementation of the National System of Conservation Units. As such it has the authority to demand the submission of information by any conservation unit and to carry out inspections of any municipal, state or federal units (MACHADO, 2001, p. 268). Said Decree also introduced regulations under the auspices of Laws $n^{\circ} 6902 / 81$ and $6938 / 81$, which governed, respectively, the establishment of Ecological Stations and Areas of Environmental Protection, as well as other measures relating to the National Environmental Policy.

In 1990, CONAMA Resolution 013/1990, using the terms "surroundings of the conservation units" and "areas surrounding the conservation units", established, in art. 2 , that all activity that might affect the biota, thereby prejudicing the areas surrounding conversation units, within a radius of ten kilometers, was to be licensed by the relevant environmental authority (Vı, op. cit.). The author goes on to state that the importance of the interface between the conservation units and their surroundings was made patently clear in the resolution and, later on, in art. 25 of the SNUC Law. The law has however been criticized due to the difficulty in applying its provisions both in large-scale conservation units, where ten kilometers is relatively insignificant in terms of fulfilling the objectives of a buffer-zone, and also in protected spaces in urban areas, in which licensing of all potentially harmful activities is not viable, given the multiplicity of use of the of land within the ten kilometer radius.

CONAMA Resolution no. 10 of October 1, 1993 defines the expression surrounding area of conservation units as "the area of vegetation cover adjacent to the limits of conservation units, as proposed in management plan, ecological/economic zoning or urban master plan, according to the management category" (Vıo, 2001, p. 353).

Art. 40 of Law no 9605, of February 12, 1998, imposes a penalty of 1 to 5 years imprisonment for direct or indirect damage to conservation units and the areas dealt with in art. 27 of Decree no. 99274/1990 (Vı, op. cit.), whilst art. 27 of Decree 3179 of September 27, 1999 stipulates the fines payable by those who commit such offenses (Vı, op. cit.).

Art. 25 of Law 9.985/2000 revoked CONAMA Resolution 013/1990. In accordance with current legal provisions, it now falls to the authority responsible for the administration of the unit, and not the Federal Council (CONAMA), to establish and regulate the occupation of the buffer zone and the use of its resources. The limits of said zone may be established in the act of setting up the conservation unit, or thereafter. In practice, it is more common for the buffer zones to be demarcated after the creation of the unit and in accordance with the determinations of the unit management plan.

It is important to bear in mind that the buffer zone is not, in fact, part of the conservation unit but is nevertheless subject, by force of Law, to mandatory zoning regulating and authorizinrg certain economic activities. According to the sole paragraph of art. 49 of the SNUC Law, the buffer zone of a conservation unit cannot, once formally defined, be transformed into an urban zone (Vı, 2001). This adds further to the complexity of the establishment of the formal boundaries of buffer zones to protected areas in urban settings.

It falls to the federal government to introduce general legislation for the conservation of natural resources, whilst the Federal Constitution confers sole jurisdiction on the municipalities to legislate on local issues, including laws governing the occupation and use of land.

As a consequence, conservation units situated entirely within the boundaries of a municipality are governed by local laws, particularly in relation to the division and use of land. In urban areas, legal norms that establish the zoning of activities must always take environmental considerations into account so as to guarantee quality of life to the local population by, for example, restricting the height of buildings or providing for route alignment in order to ensure adequate water supply and circulation and reduce the risk of fire and other accidents (OLIVEIRA e SAntos, 2004). These authors further state that, particularly in large cities, transition zones should be established between the urbanized areas and natural ecosystems to ensure that the use and occupation of land is compatible with the function of buffering or acting as a protective belt. 
The rules on zoning and use and occupation therefore start from the premise that, in order to fulfill its social function as a city, an urban area requires infrastructure, in other words it needs both public and environmental services. On the other hand, areas which are subject to excessively rigid norms are frequently, in practice, more vulnerable to irregular occupation in that land and building owners frequently abandon their properties due to the high cost of promoting any from of occupation that might generate financial return (OLIVEIRA e SANTOS, op. cit.).

In relation to the importance of buffer zones, VIo (2001, p. 349) states that such areas should assist in:

- the "formation of a protective belt around a conservation unit against external pressures from anthropic activities;

- protection of water sources, safeguarding the quality and quantity of the water;

- promotion and maintenance of the landscape and the development of ecological tourism, in conjunction with private enterprise;

- increasing leisure and recreation opportunities for the population of the areas surrounding the conservation units;

- environmental education as a basis for the increasing awareness of and respect for measures and action to preserve the environment and quality of life;

- containment of continuous and unregulated urbanization.

- consolidation of adequate use of land and of activities that are consistent with the management plan of the conservation unit”.

Vıo also refers to the problems that give rise to the need for buffer zones, including:

1. the edge effect caused by anthropic interference in the natural protective system due to increasing pressures in rural zones resulting from the relocation to such areas of industries, service activities, leisure and recreation facilities, residential condominiums and country-hotels, in a disorganized and largely unregulated manner with no region-wide planning, so that development takes place when, where and in the manner that best suits the interests of the proprietor, to the exclusion of virtually all other concerns. Current legislation classifies buffer zones as "rural areas". "The use of rural zones for urban expansion is a trend fuelled by lower land prices, and reflects the developers' desire for easy profit. Said developers dictate the rules contained in the Master Plans (when they exist), and are able to exploit loopholes in the legislation in order to privatize the substantial profits whilst spreading the high cost of basic services and the functioning of property development in such a way as to indirectly burden the taxpayer" (Vıo, 2001, p. 350).

The role of a buffer zone is not merely environmental. It also plays a part in the control of otherwise disorganized urban growth. It may also function as a basis for ecological and rural tourism.

2. The impact of anti-environmental rural practices, principally the use of pesticides and slash and burn agriculture. There is a risk of extermination of flora and fauna in the absence of the necessary precautions being taken with regard to the damaging effect of chemical agents on the environment.

3. The need to extend the physical area of the conservation units due to the reduction of habitat, a reality that has led to the extinction of innumerous species of fauna and flora.

COSTA et al. (2009) argue that, in seeking to attempt to define a buffer zone the factors to be taken into account should include the following:

a) The need for contiguity with the area to be protected, in that the aim of the buffer zone is precisely to protect the interior of the conservation unit from external impacts;

b) The nature of use/occupation of the land in the proposed area, with a view to maintaining forested areas, agricultural land and other activities that are unlikely to have a negative impact on the protected area;

c) Population density, in that densely populated areas should be excluded from the buffer zones in that they may encroach on the legally protected areas.

According to these authors, therefore, it is essential that a detailed diagnosis be made of the proposed buffer zone, including analysis of the extent to which the proposed boundaries are consistent with the applicable legislation. In fact, at present there are no specific statutory provisions as to the type of analysis that needs to be made and the criteria or parameters that should be taken into account.

The Brazilian Institute for the Environment and Renewable Natural Resources (IBAMA) which is the federal body linked to the Ministry for the Environment, an which is responsible for implementing the SNUC has helpfully set out criteria for the identification of buffer zones by means of its "Planning Methodology Guidelines “ ("Roteiro Metodológico de Planejamento"), launched in 2002 and available on the internet. This document sets out the criteria for the inclusion, exclusion and 
adaptation of areas included within the $10 \mathrm{~km}$ radius established by CONAMA Resolution 13/90 . Examples of these criteria are areas of aquifer refill, previously established urban areas and identifiable limits in the countryside, such as roads.

Above all else, the definition of a buffer zone should always be conditional upon the needs of each type of conservation unit, taking into account the reality of the communities affected by the protected zone. As a result, the criteria used to establish the precise extent of a buffer zone may vary considerably, leading to significant differences in the physical, cultural, socioeconomic aspects and in plant cover and soil use.

Once the extent of a buffer zone has been established and diagnostic tools such as previous studies and maps, ortophotos and digital images - are available, it is possible to undertake the diagnosis and measurement of the aspects referred to above, with a view to establishing socio-environmental indicators. Later on, these indicators can be mapped and submitted to integrated analysis by means of a geographical information system. This information can then lead to a synthesis map of environmental fragility, enabling the identification of critical areas that may require greater restriction in terms of use and occupation and lromoting more effective management of the conservation unit and its surrounding areas. It may also be used as a basis for public policy for the buffer zone including guidelines for the licensing of activities by the local authorities.

The definition of buffer-zones needs to be a fundamentally dynamic process, in that its aim is not to restrict or freeze economic development in the region but rather to align, guide and promote all activities within the zone that are compatible with its objectives, creating conditions in which the municipalities involved can interact with the conservation unit and develop a solid and sustainable basis for their social and economic development, whilst respecting and drawing on the characteristics and potential of the region (Vıo, 2001)

Art. 26 of the SNUC Law introduced the notion of a 'mosaic' of juxtaposed or overlapping of a range of public or private conservation units (which might or might not be of the same category). The aim of the 'mosaic' approach is integrated and participative management, taking into account the various conservation objectives "so as to compatibilize the presence of biodiversity, the valuing of socio-diversity and sustainable development in a regional context." (SNUC, 2000, art. 26)

A grouping of conservation units may only be considered a mosaic following its recognition as such by the Ministry of the Environment. The overall objective of the formation of a mosaic is the possibility of establishing an integrated administration of the space for the territorial area so as to avoid discrepancies in the policies and practices adopted by the authorities responsible for the running of the units that make up the group (VASQUES, 2008).

\section{Final considerations}

The main advantages of the establishment of a National System for Conservation Units in Brazil have been the unification of diverse conceptual viewpoints and the increase in alternative means of attaining the overall goal of preserving biodiversity.

It is important that the management plan be drawn up within the specified period of time (five years from the date of the establishment of the conservation unit) despite the significant public expenditure that will involve, as it is essential for the management of the protected area.

The buffer zone serves as a protective belt against external aggression that might undermine the physical integrity of the area. Only anthropic activities that do not undermine the aim of conservation (sustainable use) should be permitted within such zones. Such activities are therefore to be subject to specific norms and restrictions introduced by the management plan, with a view to minimizing negative impacts on the Conservation Units and subject also to measures that seek to promote the integration of the unit into the social and economic life of the neighboring communities.

As urban populations continue to grow so do the pressures to use protected areas for habitation or subsistence. In the light of this defining buffer zones for conservation units located in urban areas leads to conflicts between different interests: business, preservationist and residential.

It is not possible to establish a fixed area for buffer zones in that each space has its own specific characteristics and needs. In the case of buffer zones for conservation units located in urban areas careful investigation needs to be carried out due to the multiplicity of uses and the complexity of managing such areas, particularly in terms of public administration by local authorities.

It is therefore essential to introduce forms of planning and management for the buffer zones so as to enable economic sustenance and, at the same time, contain the 'edge effect' arising out of anthropic action in the natural system of the conservation unit. It is necessary to adopt a management model which makes provision for the integration of urban, environmental, social, economic and cultural factors. In the case of urban environments, local authorities have an important role to play in relation to the norms applicable to the use and occupation of the soil, and this in turn requires coordination of various planning and management instruments. 
Effective urban zoning should respect the local geobiophysical conditions in such as way as to guarantee the maintenance and recovery of forests while addressing issues of urban revitalization.

Areas surrounding conservation units merit adequate urbanistic treatment which takes into account, amongst other factors, the growth of cities, so as to create an area capable of acting as a protective belt, protecting forested areas from degradation by the urban nucleus.

In this context, attention needs to be focused on the following challenges: establishing physical, socioeconomic and cultural criteria as well as those pertaining to soil use and plant cover in order to define the limits of the buffer zones and their characteristics and detect and spatialize within their boundaries areas in which pressures exerted by different forms of occupation are observed as well as areas where there is a greater degree of preservation of plant cover. Consequently, on the basis of the construction of socio-environmental indicators capable of identifying the sources of pressure, the state of the environment, the impact suffered and the response of the public authorities, it becomes feasible to put forward a model of environmental planning applicable to the buffer zones of conservation units.

Mosaics of conservation units should be set up whenever possible in order to fine-tune the shared management of the protected space whilst taking into account the various difficulties relating to the political autonomy of each entity within the three levels of government of the Brazilian federation - federal, state and municipal.

\section{Bibliography}

Costa, N. M. C. da; Costa, V. C. da ; Santos, J. P. C. dos (2009) - Definição e Caracterização de Áreas de Fragilidade Ambiental, com Base em Análise Multicritério, em Zona de Amortecimento de Unidades de Conservação. In: 120 Encuentro de Geógrafos de América Latina - EGAL 2009, 2009, Montevideo - Uruguai. 12 Encuentro de Geógrafos de América Latina - Caminando en una América Latina en transformación.

IBAMA - INSTITUTO BRASILEIRO DO MEIO AMBIENTE E DOS RECURSOS NATURAIS RENOVÁVEIS (2002) Roteiro Metodológico de Planejamento voltado para Parques Nacionais, Reservas Biológicas e Estações Ecológicas. Brasília: Edições IBAMA, 136 p. available at http://www.ibama.gov. br/siucweb/unidades/roteiro_metodologico_ revisado_05_2005.pdf. Consulted in December 2009.

Machado, P. A. L. (2001) - Áreas Protegidas: a Lei $n^{\circ}$ 9985/2000. In: BENJAMIN, A. H. Direito ambiental das áreas protegidas - o regime jurídico das Unidades de Conservação. Rio de Janeiro: Forense Universitária, pp. 249 - 317.

Milano, M. S (2001) - Unidades de Conservação Técnica, Lei e Ética para a Conservação da Biodiversidade. In: BENJAMIN, A. H. Direito ambiental das áreas protegidas - o regime jurídico das Unidades de Conservação. Rio de Janeiro: Forense Universitária, pp. 3 - 41.

Olliveira, C. A. e Santos, C. J. F. (2004) - Normas de Uso e Ocupação do solo para proteção de Unidades de Conservação nas cidades. Coleção Estudos da Cidade - Tema Florestas Urbanas, no. 137, outubro, pp. 1-10.

Rodrigues, J. E. R. (2005) - Sistema Nacional de Unidades de Conservação. São Paulo: Editora Revista dos Tribunais.

VASQues, P. H. R. (2008) - A Aplicação do Plano de Manejo, Zona de Amortecimento e Corredores Ecológicos na proteção da Biodiversidade. Relatório do NIMA - Núcleo Interdisciplinar do Meio Ambiente, Rio de Janeiro. Available at http://www.nima.puc-rio.br/index.php. Consulted in Janeiro 2010.

VIo, A. P. A. 2001. Zona de amortecimento e corredores ecológicos. In: BENJAMIN, A. H. Direito ambiental das áreas protegidas - o regime jurídico das Unidades de Conservação. Rio de Janeiro: Forense Universitária, p. 348-360.

Vitalli, P. de L. (2007) - Análise dos Aspectos Jurídicos Correlatos à Zona de Amortecimento de Unidades de Conservação: Estudo de Caso da Estação Ecológica de Assis (SP), Master's degree dissertatrion, University of São Paulo, Master's Degree in Environmental Engineering. 